\title{
Effect of employee demographic characteristics and selected Human Resource Management Practices turnover intentions: A case of commercial banks in Eldoret Town, Kenya
}

\author{
Norbert P. Murupus ${ }^{1} \&$ Dr. Dinah J. Kipkebut ${ }^{2}$ \\ ${ }^{1}$ MBA student, Egerton University, Faculty of Commerce, Business Administration Department, Kenya \\ ${ }^{2}$ Lecturer, Egerton University, Faculty of Commerce, Business Administration Department, Kenya
}

\begin{abstract}
Organizational investment in Human Resources is an inevitable measure in pursuit of achievement of organizational goals. Organizations therefore must utilize a considerable amount of finances, materials and time in employee acquisition, maintenance and development. Despite the banking industries investing heavily in the acquisition and maintenance of its human resources, employees still quit their jobs in search of other alternatives. The objective of the present study is to establish the effect of employee demographic characteristics and selected Human Resource Management practices on employees' intention to turnover in the Banking industry. The study population consisted of Managerial, Clerical and Direct Sales Staff from twenty five (25) commercial banks in Eldoret town, Kenya. The study sampled 387 employees from ten (10) commercial banks. Questionnaire method was used to collect data. The data obtained was processed using the Statistical Package for Social Sciences (SPSS). Both descriptive and inferential statistics were used in data analysis; that is, Frequencies, means, standard deviation and Percentages which were presented in tables and charts. Pearson's Correlation analysis and Regression analysis were used to test the study hypotheses. The results of the multiple regression analysis showed that pay practices, procedural justice, marital status, education, job tenure and job position were critical factors in determining employee turnover intentions. The study recommends that banks should implement high commitment human resource management practices so as to enhance the retention of its employees.
\end{abstract}

Key words: Selected Human Resource Management practices, job characteristics, turnover intentions,

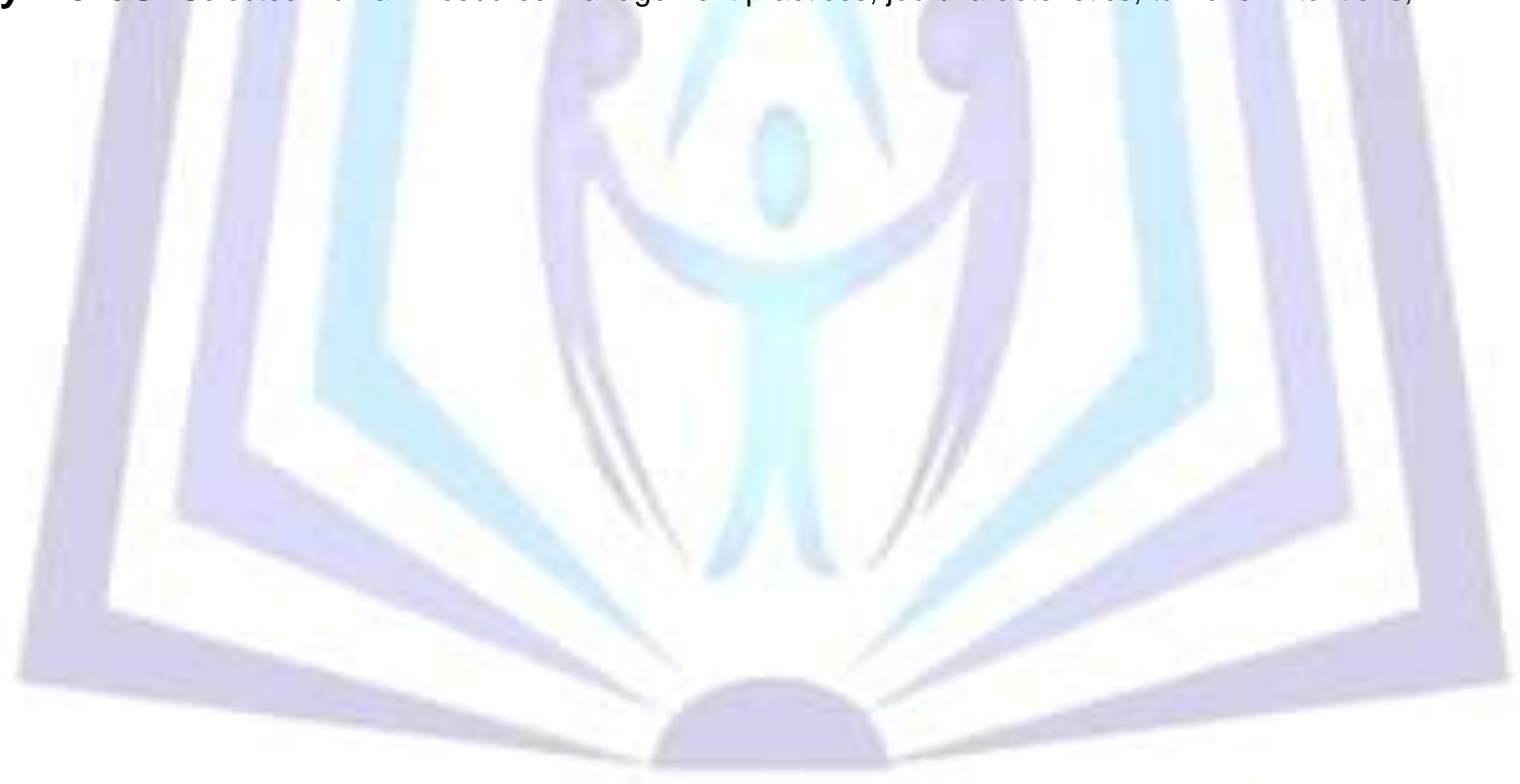

\section{Council for Innovative Research}

Peer Review Research Publishing System

\section{JOURNAL: INTERNATIONAL JOURNAL OF MANAGEMENT \& INFORMATION TECHNOLOGY}

Vol . 10, No 10

editorsijmit@gmail.com

www.ijmit.com 


\section{INTRODUCTION}

For an organization to be successful, material, financial and human resources must be set aside and be properly managed to enhance total utilization that would result to organization success. Organization success is referred to as the achievement of the organizational goals and objectives within the specified time limit. This study focused on the management of human resources (HR).Organizations must invest in time, remuneration and training in order to have competent employees who are able to produce the expected results. In this case, loss of an employee is a direct loss to the organization in terms of the organization's input in that particular employee, that is the cost and the time elapsed in recruitment of a new employee during replacement. Therefore, as Khilji \& Wang (2007) observes, employees should be motivated to remain in their current organizations by all means.

Various studies have been conducted on the factors that influence employee (HR) retention across the industries. Michel et al., (2011) conducted a study to evaluate the impact of several HR practices on employees' organizational commitment in the banking sector of Kuwait. The results showed that fifty percent of the variables confirmed previous studies and the remaining fifty percent did not support these studies due to factors such as culture and values. Komal \& Samina (2011) also conducted a research study in order to examine the impact of employee participation, job satisfaction, role clarity and organizational climate on organizational commitment of employees in different organizations of the banking industry in Islamabad both in public and private sector. The study concluded that there are other variables which impact organizational commitment other than the four variables considered. They also agree that job satisfaction plays an imminent role in commitment to organization and work.Previous studies have shown that work outcomes such as organizational commitment, job satisfaction and intention to quit have mainly been done in Western countries with limited studies being done in non-US and other non-Western based countries (Yousef, 2002; Wasti, 2003).

This study aimed to investigate the employees' intention to quit from employment in the banking industry in Eldoret town. The employee turnover intent starts from a thought by the employee to quit from employment, followed by the planning on quitting, resulting in search for alternative employment and finally, the desire to leave the current job (Altarawmneh \& AlKilani, 2010). This study focused on selected aspects of the relationship between the organization and the employees and sought to investigate whether they had any influence on employee turnover intention. The selected aspects include HRM practices and job characteristics

\section{STATEMENT OF THE PROBLEM}

Employee turnover remains one of the most persistent and frustrating problems faced by organizations. Whether it is involuntary, such as termination because of poor performance or voluntary, such as resignations, turnover is extremely costly. High turnover within the banking industry mostly results to negative impact on customer service and company revenues. Despite the many strategic actions carried out by Kenyan banks to retain their employees and improve their profits, the Annual HR Reports (2013) of the major commercial banks in Kenya indicates that an average of about $31 \%$ of employees have exited the banking industry. A report based on exit interviews, indicates that the majority of employees had left the industry in search of better employment opportunities. It was not known the exact cause of the employees' decision to leave their employer or what exactly seemed better about the other employers who were constantly being sought by the commercial banks employees. The purpose of this study, therefore, was to investigate the effect of employee demographic characteristics and selected HRM practices namely, promotional opportunities, pay practices, work/family conflict, participation in decision making and procedural justice on employees' intentions to quit from the banking industry.

\section{LITERATURE REVIEW}

\section{Turnover intentions}

Organizations invest a lot of resources on their employees in terms of induction, developing, maintaining and retaining them in their organization. However, studies have shown that organizations are finding it increasingly difficult to retain their top performers (Ovadje, 2009). Intent to leave refers to the degree of likelihood that an employee will terminate his or her membership in a work organization. Turnover has both direct and indirect costs (Lambert \& Hogan, 2009). The direct financial costs of turnover include the loss of the performance and expertise of the employee, recruitment costs, and training of new employees while the indirect costs include increased use of inexperienced staff, insufficient staffing, and decreased morale. In addition, high turnover can lead to shortages of staff, which can decrease the quality of services, increase in customer complaints and compromise the health and safety of employees. Employees are extremely crucial to the organization since their value to the organization is essentially intangible and not easily replicated (Meaghan \& Nick 2002). Juhdi, Pa'wan \& Hansaram (2013) noted that losing good employees can negatively affect an organization's competitive advantage as it would lead to reduction in productivity and quality. Therefore, managers must recognize employees as major contributors to the efficient achievement of the organization's success and thus enhance employee retention strategies (Abbasi \& Hollman 2000). According to Agyeman \& Ponniah (2014) turnover is a symptom of ineffective retention management. Thus, the aim of this study is to investigate the effectiveness of selected human resource management (HRM) practices in enhancing retention of bank employees in Kenya.

\section{Employee demographic characteristics}

Several studies have been done to establish the relationships between employee demographic characteristics and work attitudes such as organisational commitment, job satisfaction and turnover intentions (Mathieu \& Zajac, 1990; Ngigi \& Kipkebut, 2014; Kipkebut, 2013). The most commonly used characteristics are age, gender, tenure, education, job 
category and marital status. According to Agyeman \& Ponniah (2014) demographic characteristics are important as they have an influence on employee retention strategies. It is therefore expected that employee demographic characteristics will have significant influence on perception towards selected HRM practices and turnover intentions.

Gender: Studies have found conflicting results in the relationship between gender and intentions to turnover. Choong et al. (2013) found that female employees were more likely to turnover than male employees. On the other hand, Khatri et al. (2001) found that men have higher levels of turnover intentions.

Age: Studies have found an inverse relationship between age and intentions to turnover. Du Plooy \& Roodt (2013) found that employees aged 50 years and above were less likely to turnover because of the difficulty of finding alternative employment. Choong et al. (2013) found that younger employees were more likely to turnover than older employees.

Marital Status: Studies have found conflicting results in the relationship between marital status and turnover intention. Choong et al. (2013) found that single academic staff were more likely to turnover than married staff. Chughtai \& Zafar (2006) found insignificant relationships between marital status and turnover intention..

Education: Studies have found conflicting correlation between education and turnover intention. Cotton \& Tuttle (1986) found that eves of education was positively correlated with turnover intention. Highly educated employees were more likely to quit as they had better job opportunities. Other studies have found insignificant relationships between education and turnover intentions (Choong et al., 2013; Du Plooy \& Roodt, 2013).

Job Tenure: Studies have found significant relationships between tenure and turnover intentions. Fuentes (2012) found that employees who had been in one Job for a long time were more likely to quit due to need for change. Ng \& Sorensen (2008) found that highly tenured employees were more likely to stay due to familiarity with their work.

Job Position: Job position has been found to have significant effect on employee work-related behaviour. Chiu et al., (2009) found that employees who performed jobs with high demands and low control were more likely to turnover. Du Plooy \& Roodt (2013) found insignificant relationships between job level and turnover intentions.

From the above reviewed literature, the following hypothesis is proposed:

$\mathrm{H}_{0}$ 1: There are no differences in human resource management practices and turnover intentions based on employee demographic characteristics, namely: age, gender, marital status, education, job tenure and job position.

\section{Selected Human Resource Management Practices}

Several studies have found that human resource management practices play a crucial role in influencing employee attitudes and behavior (Delery and Doty, 1996; Meyer \& Smith, 2000; Whitener, 2001). Lee \& Lee (2007) reported that HRM practices such as training and development, teamwork, compensation/incentive, HR planning, performance appraisal, and employee security resulted in improved organizational performance, employee's productivity and product quality. This paper identified selected HRM practices, namely, promotional opportunities, pay practices, work/family conflict, participation in decision making and procedural justice which are likely to influence turnover intentions of the employees.

The most significant selected HRM practices that influence employee turnover are discussed below:

Work/Family conflict: According to Greenhaus and Beutell (1985) work-family conflict occurs when the demands or expectations associated with one domain (work) are incompatible with the demands or expectations associated with the other domain (family). Batt and Valcour (2003) found that effective organizational responses to work/family conflict are those that combine work/family policies with other human resource practices including work re-design and commitment enhancing incentives. The effects of such combinations enhance employee retention.

Pay practices: Pay practice is one of human resources management practice which normally refers to pay, wage, salary and benefit (Mudor \& Tooksoon, 2011). Abassi \& Hollman (2000) found that salary growth resulted in reduced turnover among high performing employees. Hai-Yan \& Baum (2006) found that turnover was high among high quality human resources in the hospitality sector because of demanding work, low wages and uncertain opportunities for promotion.

Promotional opportunities: Promotional opportunities refer to the degree to which an employee perceives his or her chances to grow and be promoted are available within the organisation (Lambert, Hogan \& Jiang, 2008). Miller \& Wheeler (1992) found that the lack of meaningful work and opportunities for promotion significantly influenced employees' intentions to leave an organization. Besides promotion opportunities, the evaluation criteria used in the promotion and reward system also had significant effects on employees' turnover intentions (Quarles 1994). lles et al. (1990) reported that the absence or blockage of opportunities for advancement was likely to result in lower organisational commitment and high turnover.

Procedural Justice: Procedural justice refers to the fairness of the process used in making outcome allocation decisions (Greenberg, 1987). They suggested that people perceived fairness when they have an opportunity to influence the process that led to outcome decisions. According to Colquitt et al. (2001) a fair procedure is one that is applied consistently, is free from bias, is based on accurate information, has some mechanism for correcting wrong decisions, conforms to ethical standards, and gives those affected a voice. Dirks \& Ferrin (2002) noted that procedural justice was a source of trust and thus signaled to employees that they were respected and valued by their leader. Therefore, when 
employees believe that their managers used fair procedures in making work-related decisions, they were less likely to want to quit because they believed that their interests would be protected by their managers (Poon, 2012)

Participation in Decision Making: Participation in decision making is the degree to which employees are allowed to provide meaningful input into major decisions that guide and shape the organisation (Lambert et al., 2008). Input into decision making is concerned with how power is distributed within an organization (Wright, et al 1997). Studies have found that the extent to which management is perceived to be receptive to employee ideas has been positively associated with high levels of organisational commitment and therefore low levels of turnover intentions (Allen \& Meyer, 1990; McElroy, 2001). Employees who are allowed to participate in decision making generally view their job in a more positive light resulting in greater job satisfaction and thus, lower levels of turnover intentions.

From the above reviewed literature, the following hypotheses are proposed:

$\mathrm{H}_{\mathrm{O}}$ 2: Work/family conflict has no significant effect on employee turnover intentions

$\mathrm{H}_{\mathrm{O}}$ 3: Pay practices have no significant effect on employee turnover intentions

$\mathrm{H}_{\circ} 4$ : Promotional opportunities have no significant effect on employee turnover intentions

$\mathrm{H}_{\circ}$ : Procedural justice has no significant effect on employee turnover intentions

$\mathrm{H}_{\circ}$ : Participation in decision making has no significant effect on employee turnover intentions

$\mathrm{H}_{\mathrm{O}}$ 7: The combined effects of employee demographic characteristics and HRM practices have no significant effect on employee turnover intentions.

\section{METHOD}

This study adopted descriptive research design. Purposive sampling was used to select ten (10) commercial banks from a total of 25 banks at Eldoret town in Kenya. The respondents of the study were managers, clerical and direct sales employees. The population of the study consisted of 442 clerical employees, 170 direct sales employees and 58 managers. Stratified random sampling was used to select 210 clerical employees and 119 direct sales employees while census was used for managers giving a total of 387 respondents. Questionnaires were distributed to the respondents through a 'drop and pick' method. A total of 253 questionnaires were successfully filled giving a response rate of $65 \%$. The description of the respondents is presented in Table 1 below.

Table 1: Summary of demographic characteristics of the respondents

\begin{tabular}{|l|l|l|}
\hline Variables & Frequency & Percent (\%) \\
\hline Gender & 130 & 51.4 \\
Female & 123 & 48.6 \\
\hline & 253 & 100 \\
\hline Age & 32 & $12 . .6$ \\
Below 25 years & 173 & 68.4 \\
$25-34$ year & 33 & 13.0 \\
$35-44$ years & 15 & 6.0 \\
\hline Marital status & 253 & 100 \\
Single & 133 & \\
Married & 120 & 47.4 \\
\hline & 253 & 52.6 \\
\hline Level of education & 37 & 100 \\
\hline Diploma and below & 177 & 10.6 \\
Undergraduate degree & 39 & 100 \\
\hline Masters degree & 253 & \\
\hline & & 15.4 \\
\hline
\end{tabular}




\begin{tabular}{|l|l|l|}
\hline Job tenure & & \\
Below 5 years & 169 & 66.8 \\
$5-10$ years & 53 & 20.9 \\
11 years and above & 31 & 12.3 \\
\hline & 253 & 100 \\
\hline Position tenure & & \\
Below 2 years & 49 & 38.9 \\
$2-5$ years & 67 & 53.2 \\
6 years and above & 10 & 7.9 \\
\hline & 253 & 100 \\
\hline
\end{tabular}

\section{Measurement of variables}

Following extensive review of the literature, the questionnaire to collect data for the study was developed and measured on a 5-point likert scale from strongly agree to strongly disagree, Where point -1 indicates Strongly Disagree, 2-Disagree, 3-Uncertain, 4-Agree and 5-Strongly Disagree. Cronbach reliability coefficients were computed for each variable and the results showed acceptable reliability for all measures as follows; promotional opportunities $(\alpha=0.7404)$; pay practices ( $\alpha$ $=07813)$; work/family $(\alpha=0.7332)$; participation in decision making $(\alpha=0.8446)$; procedural justice $(\alpha=0.7820)$ and turnover intentions $(\alpha=0.8162)$. The demographic characteristics are as follows: gender, marital status, age, job position, job tenure and level of education.

\section{RESULTS}

The testing of hypotheses was subjected to statistical analysis as shown below. Independent samples t-tests and one-way Analysis of Variance (ANOVA) was carried out to test Hypothesis One. Pearson Correlation analysis was carried out to test Hypothesis Two to Six. Finally, multiple regression analyses were conducted to test Hypothesis Seven.

\section{Results of Independent samples t-tests and one-way Analysis of Variance (ANOVA)}

$\mathrm{H}_{0}$ 1: There are no differences in human resource management practices and turnover intentions based on employee demographic characteristics, namely: age, gender, marital status, education, job tenure and job position.

\section{-Gender}

Table 2: Results of Independent Samples t-test exploring differences in HRM practices and intentions to turnover based on gender

\begin{tabular}{|c|c|c|c|c|c|c|}
\hline & & $\mathbf{N}$ & Mean & $\begin{array}{c}\text { Std. } \\
\text { Deviation }\end{array}$ & $t$-value & Sign. \\
\hline \multirow[t]{2}{*}{ Promotional opportunities } & Male & 130 & 10.82 & 2.92 & -0.513 & 0.609 \\
\hline & Female & 123 & 11.00 & 2.80 & & \\
\hline \multirow[t]{2}{*}{ Pay practices } & Male & 130 & 15.83 & 4.52 & 0.404 & 0.686 \\
\hline & Female & 123 & 15.60 & 4.50 & & \\
\hline \multirow[t]{2}{*}{ Work/family conflict } & Male & 130 & 16.98 & 3.57 & 3.173 & 0.002 \\
\hline & Female & 123 & 15.28 & 4.85 & & \\
\hline \multirow[t]{2}{*}{ Participation in decision making } & Male & 130 & 17.36 & 3.72 & -1.254 & 0.211 \\
\hline & Female & 123 & 18.01 & 4.46 & & \\
\hline \multirow[t]{2}{*}{ Procedural justice } & Male & 130 & 15.34 & 4.27 & -1.531 & 0.127 \\
\hline & Female & 123 & 16.19 & 4.55 & & \\
\hline \multirow[t]{2}{*}{ Intentions to turnover } & Male & 130 & 12.02 & 4.41 & 1.247 & 0.213 \\
\hline & Female & 123 & 11.31 & 4.69 & & \\
\hline
\end{tabular}


The results in Table 2 show that, with the exception of work/family conflict, there were no statistically significant differences in the means scores of promotional opportunities, pay practices, participation in decision making, procedural justice and intentions to turnover among male and female employees $(p>0.05)$. The analysis has shown that male respondents had higher mean scores for work/family conflict $(M=16.98)$ than female respondents $(M=15.28, p=0.002)$. This shows that male employees experienced work/family conflict more than female employees.

\section{Marital status}

Table 3: Results of Independent Samples t-test exploring differences in HRM practices and intentions to turnover based on marital status

\begin{tabular}{|c|c|c|c|c|c|c|}
\hline & $\begin{array}{l}\text { Marital } \\
\text { status }\end{array}$ & $\mathbf{N}$ & Mean & $\begin{array}{c}\text { Std. } \\
\text { Deviation }\end{array}$ & $t$-Value & Sig. \\
\hline \multirow[t]{2}{*}{ Promotional opportunities } & Married & 133 & 10.98 & 2.98 & .423 & 0.673 \\
\hline & Unmarried & 120 & 10.83 & 2.73 & & \\
\hline \multirow[t]{2}{*}{ Pay practices } & Married & 133 & 15.30 & 4.83 & -1.562 & 0.119 \\
\hline & Unmarried & 120 & 16.18 & 4.08 & & \\
\hline \multirow[t]{2}{*}{ Work/family conflict } & Married & 133 & 16.60 & 4.12 & 1.743 & 0.083 \\
\hline & Unmarried & 120 & 15.66 & 4.48 & & \\
\hline \multirow[t]{2}{*}{ Participation in decision making } & Married & 133 & 17.09 & 3.89 & -2.413 & 0.017 \\
\hline & Unmarried & 120 & 18.33 & 4.24 & & \\
\hline \multirow[t]{2}{*}{ Procedural justice } & Married & 133 & 15.79 & 4.70 & .146 & 0.884 \\
\hline & Unmarried & 120 & 15.71 & 4.10 & & \\
\hline \multirow[t]{2}{*}{ Intentions to turnover } & Married & 133 & 10.90 & 4.53 & -2.884 & 0.004 \\
\hline & Unmarried & 120 & 12.53 & 4.45 & & \\
\hline
\end{tabular}

The results in Table 3 show that, with the exception of participation in decision making and intentions to turnover, there were no statistically significant differences in the means scores of promotional opportunities, pay practices, work/family conflict and procedural justice among married and single employees $(p>0.05)$. The analysis has shown that unmarried respondents had higher mean scores for participation in decision making $(M=18.33)$ than married respondents $(M=$ 17.09, $p=0.017$ ).

The analysis has also shown that married respondents had lower mean scores for intentions to turnover $(M=10.90)$ than unmarried respondents $(M=12.53, p=0.004)$. Due to family responsibilities, married employees are less likely to quit their jobs unlike unmarried employee

\section{Age}

Table 4: Results of ANOVA exploring differences in human resource management practices and turnover intentions based on the age of respondents

\begin{tabular}{|c|c|c|c|c|c|c|}
\hline Variables & $\begin{array}{l}\text { Age of } \\
\text { respondents }\end{array}$ & $\mathbf{N}$ & Mean & $\begin{array}{l}\text { Std. } \\
\text { Deviation }\end{array}$ & F(ANOVA) & Sig. \\
\hline \multirow[t]{4}{*}{ Promotional opportunities } & Below 25 years & 32 & 11.88 & 2.93 & \multirow[t]{4}{*}{8.469} & \multirow[t]{4}{*}{0.000} \\
\hline & $25-34$ years & 173 & 11.20 & 2.60 & & \\
\hline & $35-44$ years & 33 & 9.00 & 2.74 & & \\
\hline & 45 years and above & 15 & 9.60 & 3.81 & & \\
\hline \multirow[t]{4}{*}{ Pay practices } & Below 25 years & 32 & 16.63 & 3.50 & \multirow[t]{4}{*}{4.327} & \multirow[t]{4}{*}{0.000} \\
\hline & $25-34$ years & 173 & 15.65 & 4.45 & & \\
\hline & $35-44$ years & 33 & 16.82 & 3.70 & & \\
\hline & 45 years and above & 15 & 12.20 & 6.66 & & \\
\hline \multirow[t]{2}{*}{ Work/family conflict } & Below 25 years & 32 & 15.50 & 4.78 & \multirow[t]{2}{*}{3.463} & \multirow[t]{2}{*}{0.017} \\
\hline & 25-34 years & 173 & 15.83 & 4.25 & & \\
\hline
\end{tabular}




\begin{tabular}{|c|c|c|c|c|c|c|}
\hline & $\begin{array}{l}35-44 \text { years } \\
45 \text { years and above }\end{array}$ & $\begin{array}{l}33 \\
15\end{array}$ & $\begin{array}{l}17.18 \\
19.00\end{array}$ & $\begin{array}{l}4.26 \\
2.73\end{array}$ & & \\
\hline \multirow{4}{*}{$\begin{array}{l}\text { Participation in decision } \\
\text { making }\end{array}$} & Below 25 years & 32 & 20.22 & 4.53 & \multirow[t]{4}{*}{14.112} & \multirow[t]{4}{*}{0.000} \\
\hline & 25-34 years & 173 & 17.93 & 3.77 & & \\
\hline & $35-44$ years & 33 & 15.88 & 3.74 & & \\
\hline & 45 years and above & 15 & 13.27 & 2.69 & & \\
\hline \multirow[t]{4}{*}{ Procedural justice } & Below 25 years & 32 & 17.88 & 2.39 & \multirow[t]{4}{*}{3.423} & \multirow[t]{4}{*}{0.018} \\
\hline & 25-34 years & 173 & 15.62 & 4.60 & & \\
\hline & $35-44$ years & 33 & 15.03 & 4.82 & & \\
\hline & 45 years and above & 15 & 14.33 & 3.35 & & \\
\hline \multirow[t]{4}{*}{ Intentions to turnover } & Below 25 years & 32 & 10.56 & 4.90 & \multirow[t]{4}{*}{3.941} & \multirow[t]{4}{*}{0.009} \\
\hline & $25-34$ years & 173 & 12.27 & 4.16 & & \\
\hline & $35-44$ years & 33 & 9.64 & 4.73 & & \\
\hline & 45 years and above & 15 & 11.73 & 6.35 & & \\
\hline
\end{tabular}

The results in Table 4 has shown that the mean scores of promotional opportunities, pay practices, work/family conflict, participation in decision making, procedural justice and intentions to turnover differed significantly based on the age of the respondents $(p<0.05)$. The results shows that there were statistically significant differences in the mean scores of promotional opportunities among the four age Groups $(F=8.469, \mathrm{p}=0.000)$. The mean scores have shown that respondents aged 35 years and above were more dissatisfied with their promotional opportunities than respondents aged 34 years and below.

The results shows that there were statistically significant differences in the mean scores of pay practices among the four age Groups $(F=4.327, \mathrm{p}=0.000)$. The mean scores have shown that respondents aged 44 years and below were more satisfied with their pay practices than respondents aged 45 years and above.

In relation to work/family conflict, the analysis has shown that respondents aged 35 years and above experienced more work/family conflict than respondents aged 34 years and below $(F=3.463, p=0.017)$.

The analysis has shown that there were significant differences in the mean scores of participation in decision making based on the age of the respondents $(F=14.112, P=0.000)$. The mean scores show that respondents aged 44 years and below were more satisfied with participation in decision making than respondents aged 45 years and above.

The analysis has also shown that there were statistically significant differences in the mean scores of procedural justice among the four age Groups $(F=3.423, p=0.018)$. The mean scores have shown that respondents aged 44 years and below perceived that there was procedural justice in decisions making unlike respondents aged 45 years and above.

The analysis has also shown that there were statistically significant differences in the mean scores of turnover intentions among the four age Groups $(F=3.941, p=0.009)$. The post-hoc comparison using Tukey has shown that the mean scores of respondents aged 25 - 34 years was significantly higher than respondents aged 35-44 years.

\section{Job position}

Table 5: Results of ANOVA exploring differences in HRM practices and intentions to turnover based on the job position

\begin{tabular}{|c|c|c|c|c|c|c|}
\hline & & $\mathrm{N}$ & Mean & $\begin{array}{c}\text { Std. } \\
\text { Deviation }\end{array}$ & $F($ ANOVA) & Sig. \\
\hline \multirow[t]{3}{*}{ Promotional opportunities } & Managerial & 50 & 11.36 & 2.95 & 1.641 & 0.196 \\
\hline & Clerical & 121 & 10.58 & 2.94 & & \\
\hline & Direct sales & 82 & 11.11 & 2.65 & & \\
\hline \multirow[t]{2}{*}{ Pay practices } & Managerial & 50 & 14.80 & 5.21 & 1.304 & 0.273 \\
\hline & Clerical & 121 & 15.94 & 4.35 & & \\
\hline
\end{tabular}




\begin{tabular}{|l|l|r|r|r|l|l|}
\hline \multirow{5}{*}{ Work/family conflict } & Direct sales & 82 & 15.95 & 4.23 & & \\
& Managerial & 50 & 17.34 & 4.71 & 11.348 & 0.000 \\
\cline { 2 - 7 } & Clerical & 121 & 16.87 & 4.65 & & \\
\cline { 2 - 7 } & Direct sales & 82 & 14.38 & 2.76 & & 0.000 \\
\hline Participation in decision making & Managerial & 50 & 15.90 & 4.32 & 11.380 & \\
\cline { 2 - 8 } & Clerical & 121 & 17.39 & 3.83 & & 0.661 \\
\cline { 2 - 8 } & Direct sales & 82 & 19.18 & 3.87 & & \\
\hline Procedural justice & Managerial & 50 & 16.22 & 4.82 & 0.414 & \\
\cline { 2 - 7 } & Clerical & 121 & 15.73 & 4.51 & & \\
\hline Intentions to turnover & Direct sales & 82 & 15.50 & 4.03 & & \\
\hline
\end{tabular}

The results in Table 5 has shown that, with the exception of work/family conflict and participation in decision making, the mean scores of promotional opportunities, pay practices, procedural justice and intentions to turnover did not differ significantly based on job position $\quad(p>0.05)$. The results shows that there were statistically significant differences in the mean scores of work/family conflict among the three job position Groups $(F=11.348, p=0.000)$. The mean scores have shown that managerial and clerical respondents experienced higher levels of work/family conflict than direct sales employees. It is possible that most of the direct sales employees were young and thus did not have family responsibilities.

The analysis has also shown that direct sales respondents had higher mean scores for participation in decision making than clerical and managerial respondents $(F=11.380, p=0.000)$. Direct sales employees, who work on set targets, are expected to have regular consultations with their supervisors thus enhancing their participation in decision making.

\section{Job tenure}

Table 6: Results of ANOVA exploring differences in HRM practices and intentions to turnover based on the age of the respondents

\begin{tabular}{|c|c|c|c|c|c|c|}
\hline & & $\mathbf{N}$ & Mean & $\begin{array}{c}\text { Std. } \\
\text { Deviation }\end{array}$ & $\begin{array}{c}F \\
\text { (ANOVA) }\end{array}$ & Sig \\
\hline \multirow[t]{3}{*}{ Promotional opportunities } & Less than 5 years & 169 & 11.10 & 2.66 & 11.899 & 0.000 \\
\hline & $5-10$ years & 53 & 11.57 & 2.54 & & \\
\hline & 11 years and above & 31 & 8.71 & 3.45 & & \\
\hline \multirow[t]{3}{*}{ Pay } & Less than 5 years & 169 & 15.93 & 4.26 & 0.873 & 0.419 \\
\hline & $5-10$ years & 53 & 15.00 & 4.07 & & \\
\hline & 11 years and above & 31 & 15.77 & 6.20 & & \\
\hline \multirow[t]{3}{*}{ Work/family conflict } & Less than 5 years & 169 & 16.07 & 3.88 & 5.758 & 0.004 \\
\hline & $5-10$ years & 53 & 15.13 & 5.76 & & \\
\hline & 11 years and above & 31 & 18.35 & 2.81 & & \\
\hline \multirow{3}{*}{$\begin{array}{l}\text { Participation in decision } \\
\text { making }\end{array}$} & Less than 5 years & 169 & 17.88 & 4.10 & 3.020 & 0.050 \\
\hline & $5-10$ years & 53 & 18.02 & 4.20 & & \\
\hline & 11 years and above & 31 & 16.00 & 3.62 & & \\
\hline \multirow[t]{3}{*}{ Procedural justice } & Less than 5 years & 169 & 15.59 & 4.56 & 0.896 & 0.409 \\
\hline & $5-10$ years & 53 & 15.68 & 4.45 & & \\
\hline & 11 years and above & 31 & 16.74 & 3.41 & & \\
\hline
\end{tabular}




\begin{tabular}{|l|l|c|c|c|c|c|}
\hline Intentions to turnover & Less than 5 years & 169 & 11.75 & 4.31 & 5.498 & 0.005 \\
& $5-10$ years & 53 & 12.75 & 4.18 & & \\
\cline { 2 - 7 } & 11 years and above & 31 & 9.42 & 5.70 & & \\
\hline
\end{tabular}

The results in Table 6 have shown that the mean scores of pay and procedural justice did not differ significantly based on job tenure $(p>0.05)$.

The results shows that there were statistically significant differences in the mean scores of promotional opportunities among the three job tenure Groups $(F=11.899, p=0.000)$. The mean scores have shown that employees who have worked in the banks for 11 years and above were less satisfied with their promotional opportunities than respondents who have worked for 10 years and below.

The analysis has also shown that respondents who have worked in the banks for 11 years and above had higher mean scores for work/family conflict than respondents who have worked for 10 years and below $(F=5.758, p=0.004)$.

The analysis has also shown that respondents who have worked in the banks for 11 years and above had lower mean scores for participation in decision making than respondents who have worked for 10 years and below $(F=3.020, p=$ 0.050).

Finally, the results shows that there were statistically significant differences in the mean scores of intentions to turnover among the three job tenure Groups $(F=5.498, p=0.005)$. The mean scores have shown that respondents who have worked in the banks for 11 years and above had lower mean scores than respondents who have worked for 10 years and below.

\section{Level of education}

Table 7: Results of ANOVA exploring differences in HRM practices and intentions to turnover based on the age of the respondents

\begin{tabular}{|c|c|c|c|c|c|c|}
\hline & & $\mathbf{N}$ & Mean & $\begin{array}{l}\text { Std. } \\
\text { Deviation }\end{array}$ & $F(A N O V A)$ & Sig. \\
\hline \multirow[t]{3}{*}{ Promotional opportunities } & Diploma & 37 & 10.30 & 2.90 & 1.516 & 0.222 \\
\hline & Bachelor's degree & 177 & 10.92 & 2.89 & & \\
\hline & Postgraduate & 39 & 11.44 & 2.61 & & \\
\hline \multirow[t]{3}{*}{ Pay practices } & Diploma & 37 & 14.57 & 4.16 & 2.221 & 0.111 \\
\hline & Bachelor's degree & 177 & 16.10 & 4.45 & & \\
\hline & Postgraduate & 39 & 15.10 & 4.88 & & \\
\hline \multirow[t]{3}{*}{ Work/family conflict } & Diploma & 37 & 15.84 & 3.65 & 2.315 & 0.101 \\
\hline & Bachelor's degree & 177 & 15.92 & 4.54 & & \\
\hline & Postgraduate & 39 & 17.51 & 3.62 & & \\
\hline \multirow{3}{*}{$\begin{array}{l}\text { Participation in decision } \\
\text { making }\end{array}$} & Diploma & 37 & 17.62 & 5.21 & 0.067 & 0.935 \\
\hline & Bachelor's degree & 177 & 17.64 & 3.99 & & \\
\hline & Postgraduate & 39 & 17.90 & 3.50 & & \\
\hline \multirow[t]{3}{*}{ Procedural justice } & Diploma & 37 & 15.57 & 3.19 & 0.441 & 0.644 \\
\hline & Bachelor's degree & 177 & 15.66 & 4.52 & & \\
\hline & Postgraduate & 39 & 16.36 & 4.95 & & \\
\hline \multirow[t]{3}{*}{ Intentions to turnover } & Diploma & 37 & 9.78 & 3.21 & 4.049 & 0.019 \\
\hline & Bachelor's degree & 177 & 11.90 & 4.63 & & \\
\hline & Postgraduate & 39 & 11.68 & 4.56 & & \\
\hline
\end{tabular}

The results in Table 7 has shown that with the exception of intentions to turnover, the mean scores of promotional opportunities, pay practices, work/family conflict, participation in decision making and procedural justice did not differ significantly based on the level of education of the respondents $(p>0.05)$. The results shows that there were statistically significant differences in the mean scores of intentions to turnover among the three levels of education $\quad(F=4.049, p=$ 
0.019). The mean scores have shown that respondents with undergraduate and postgraduate degrees were more likely to turnover than respondents with Diploma. This suggests that highly educated employees had more employment opportunities than less educated employees.

\section{Results of Pearson Correlation analysis}

Hypotheses Two to Six sought to determine the effect of selected human resource management practices on intentions to turnover. These hypotheses were tested using Pearson's Correlation analysis which determines the strength and direction of the relationships.

Table 8: Pearson's Correlation analysis exploring the relationship among selected human resource management practices and intentions to turnover

\begin{tabular}{|c|c|c|c|c|c|c|}
\hline & $\begin{array}{l}\text { Promotional } \\
\text { opportunities }\end{array}$ & $\begin{array}{c}\text { Pay } \\
\text { practices }\end{array}$ & $\begin{array}{l}\text { Work/ } \\
\text { family } \\
\text { conflict }\end{array}$ & $\begin{array}{l}\text { Participation } \\
\text { in decision } \\
\text { making }\end{array}$ & $\begin{array}{l}\text { Procedural } \\
\text { justice }\end{array}$ & $\begin{array}{l}\text { Intentions to } \\
\text { turnover }\end{array}$ \\
\hline Promotional opportunities & 1 & $.348\left({ }^{\star \star}\right)$ & $-.322\left({ }^{\star *}\right)$ & $.362\left({ }^{* *}\right)$ & $.398\left({ }^{* *}\right)$ & $-.162\left({ }^{* *}\right)$ \\
\hline Pay practices & $.348(* *)$ & 1 & $-.279\left(^{* *}\right)$ & $.463\left({ }^{* *}\right)$ & $.568\left({ }^{* *}\right)$ & $-.408\left(^{* \star}\right)$ \\
\hline Work/family conflict & $-.322\left({ }^{* \star}\right)$ & $-.279\left(^{\star *}\right)$ & 1 & $-.408\left(^{* *}\right)$ & $-.292\left(^{\star *}\right)$ & $.170\left({ }^{\star \star}\right)$ \\
\hline $\begin{array}{l}\text { Participation in decision } \\
\text { making }\end{array}$ & $.362\left({ }^{\star *}\right)$ & $.463\left({ }^{\star *}\right)$ & $-.408\left(^{\star \star}\right)$ & 1 & $.530\left({ }^{\star *}\right)$ & $-.184\left(^{* *}\right)$ \\
\hline Procedural justice & $.398\left({ }^{\star *}\right)$ & $.568\left({ }^{\star *}\right)$ & $-.292\left(^{\star \star}\right)$ & $.530(* *)$ & 1 & $-.526\left({ }^{* \star}\right)$ \\
\hline Intentions to turnover & $-.162\left({ }^{* *}\right)$ & $-.408\left({ }^{\star \star}\right)$ & $.170\left({ }^{* \star}\right)$ & $-.184\left({ }^{* *}\right)$ & $-.526\left(^{\star *}\right)$ & 1 \\
\hline
\end{tabular}

\section{$H_{0}$ 2: Promotional Opportunities has no significant effect on intentions to turnover.}

The results in Table 8 showed that there was a weak, significant negative relationship between promotional opportunities and intentions to turnover $(r=-0.162, \mathrm{p}<0.05)$. This suggests that turnover intentions were high among employees who were dissatisfied with their promotional opportunities.

\section{$H_{0}$ 3: Pay has no significant effect on intentions to turnover}

The results in Table 8 showed that there was a moderate, significant negative relationship between pay practices and intentions to turnover $(r=-0.408, p<0.05)$. This suggests that intention to turnover was high among employees who were dissatisfied with their pay.

\section{$\mathrm{H}_{\mathrm{O}} 4$ : Work/Family conflict has no significant effect on intentions to turnover}

The results in Table 8 showed that there was a weak, significant positive relationship between work/family conflict and intentions to turnover $(r=0.170, p<0.05)$. This suggests that increase in work/family conflict enhanced employees desire to quit the bank.

\section{$H_{0}$ 5: Procedural Justice has no significant effect on intentions to turnover}

The results in Table 8 showed that there was a moderate, significant negative relationship between procedural justice and intentions to turnover $(r=-0.526, p<0.05)$. This suggests that turnover intentions were high among employees who perceived that procedures used by their banks were unfair.

\section{$H_{0}$ 6: Participation in Decision Making has no significant effect on intentions to turnover}

The results in Table 8 showed that there was a weak, significant negative relationship between participation in decision making and intentions to turnover $(r=-0.184, \mathrm{p}<0.05)$. This suggests that employees who are involved in decision making in their banks are less likely to quit their jobs. 


\section{Results of multiple regression analysis}

$\mathrm{H}_{0} 7$ : The combined effects of HRM practices and job characteristics do not have a significant effect on intentions to turnover

Table 9: Results of multiple regression analysis establishing the combined effects of human resource management practices and job characteristics on intentions to turnover

\begin{tabular}{|c|c|c|c|c|c|c|c|}
\hline & \multicolumn{2}{|c|}{$\begin{array}{l}\text { Unstandardized } \\
\text { Coefficients }\end{array}$} & \multirow{2}{*}{$\begin{array}{c}\begin{array}{c}\text { Standardized } \\
\text { Coefficients }\end{array} \\
\text { Beta }\end{array}$} & \multirow[t]{2}{*}{$t$-value } & \multirow[t]{2}{*}{ Sig. } & \multicolumn{2}{|c|}{ Collinearity Statistics } \\
\hline & $B$ & Std. Error & & & & Tolerance & VIF \\
\hline (Constant) & 8.262 & 3.425 & & 2.412 & .017 & & \\
\hline Gender of respondents & -.596 & .498 & -.066 & -1.198 & .232 & .808 & 1.238 \\
\hline Age of respondents & -.154 & .519 & -.024 & -.298 & .766 & .388 & 2.575 \\
\hline Job position & 1.031 & .449 & .161 & 2.299 & .022 & .492 & 2.034 \\
\hline Marital status & 2.346 & .547 & .258 & 4.288 & .000 & 670 & 1.492 \\
\hline Job tenure & 1.259 & .517 & .194 & 2.435 & .016 & .379 & 2.635 \\
\hline Level of education & 2.111 & .454 & .254 & 4.646 & .000 & .806 & 1.240 \\
\hline Promotional opportunities & .179 & .096 & .112 & 1.860 & .064 & .663 & 1.508 \\
\hline Pay & -.249 & .065 & -.246 & -3.859 & .000 & .594 & 1.684 \\
\hline Work/family conflict & .052 & .061 & .049 & .852 & .395 & .722 & 1.386 \\
\hline $\begin{array}{l}\text { Participation in decision } \\
\text { making }\end{array}$ & .102 & .076 & .092 & 1.342 & .181 & .515 & 1.941 \\
\hline Procedural justice & -.493 & .072 & -.478 & -6.895 & .000 & .503 & 1.990 \\
\hline
\end{tabular}

a Dependent Variable: Intentions to turnover

\section{Model Summary}

\begin{tabular}{|l|r|r|r|r|r|}
\hline Model & $\mathrm{R}$ & \multicolumn{1}{|c|}{ R Square } & Adjusted R Square & \multicolumn{1}{|c|}{$\boldsymbol{F ( A N O V A )}$} & Sign \\
\hline 1 & $.646^{\mathrm{a}}$ & .417 & .391 & 15.686 & 0.000 \\
\hline
\end{tabular}

a. Predictors: (Constant), Procedural justice, Marital status, Level of education, Gender of respondents, Work/family conflict, Promotional opportunities, Job position, Pay practices, Participation in decision making, Age of respondents, Duration worked in the bank

The regression analysis in Table 9 shows that employee demographic characteristics and selected human resource management practices accounted for $41.7 \%$ of the variance in turnover intentions among the respondents from commercial banks in Eldoret town $(R$ square $=0.417$ ). This shows that $58.3 \%$ of the variance in employee turnover intentions was explained by factors not in the study. The standardized beta coefficients indicate that procedural justice $(\beta=-0.478, p=0.000)$, marital status $(\beta=0.258, p=0.000)$, level of education $(\beta=0.254, p=0.000)$, pay practices $(\beta=-0.246, p=0.000)$, job tenure $(\beta=0.194, p=0.016)$ and job position $(\beta=0.161, p=0.022)$ were significant predictors of employee turnover intentions.

\section{DISCUSSION}

The main objective of the study was to determine the effect of human resource management practice and job characteristics on employee turnover intentions of commercial banks in Eldoret town.

Gender: The analysis has shown that male employees experienced more work/family conflict than female employees. This is contrary to findings by Calvo-Salguero et al. (2010) who found that women experienced higher levels of Work Interfering with family responsibilities.

Marital Status: The analysis has shown that unmarried employees participated more in decision making that married employees. it is possible that the unmarried employees are young, direct sales employees who work on set targets which are jointly set with their supervisors. In relation to turnover intentions, the analysis showed that married employees were more likely to turnover than unmarried employees. This is consistent with findings by Choong et al. (2013) who found that married academics were less likely to turnover due to family responsibilities. 
Age: The analysis has shown that older employees were dissatisfied with HRM practices and experienced more work/family conflict and less likely to turnover. Several studies have found that older employees were more likely to stay in their organisations due to declining job opportunities (Karsh, Bookse and Sainfort, 2005; Choong et al., 2013; Kipkebut, 2013).

Job position: The analysis has shown that managers experienced more work/family conflict than clerical and direct sales employees. Due their managerial responsibilities, it is expected that managers work long hours which may interfere with their family life. On the other hand, direct sales and clerical staff were more satisfied with participation in decision making than managers. For the direct sales and clerical staff, managers offer support at the branch levels while the managers have to consult their superiors at the banks headquarters.

Job tenure: The analysis has shown that employees who have worked in the bank for 11 years and above were dissatisfied with their promotional opportunities, experienced more work/family conflict and were less likely to take part in decision making. This is contrary to findings by Kipkebut (2013) which found that employees who had worked in the organisation for a long time were more likely to quit.

Education: The analysis has shown that employees with Diploma were less likely to turnover as compared to employees with bachelors and postgraduate degrees. Various studies have found that employees with higher levels of education have higher expectations and chances of employability than employees with lower levels of education (Kipkebut, 2013; Choong et al., 2013; Mathieu and Zajac, 1990).

Promotional opportunities: The results showed that promotional opportunities were negatively correlated with turnover intentions, which suggests that turnover intentions were high among employees who were dissatisfied with their promotional opportunities. This finding was consistent with Miller and Wheeler (1992) who found that lack of meaningful work and opportunities for promotion significantly influenced employee's intention to leave an organization.

Pay practices On pay practices, the study found a negative correlation between pay practices and intentions to turnover. This suggests that bank employees who were not paid well for performing their jobs were more likely to desire to quit their jobs. This finding is consistent with studies by Bergmann, Bergmann, and Grahn (1994) which found out that a well-designed employee pay and benefit packages were effective tools for attracting, motivating, and retaining employees. Similarly, Nivethitha, Dyaram \& Kamalanabhan (2014) reported that the consequences of frequently underpaid and undertrained employees leads to low levels of motivation, job dissatisfaction, high turnover and ultimately dissatisfied customers.

Work/family conflict: The results showed that there was a positive relationship between work/family conflict and turnover intentions. This is consistent with the study by Lambert et al. (2006) who found that employees who experienced work/family conflict had high levels of stress resulting in job dissatisfaction and thus the desire to quit the job.

Participation to decision making: On participation to decision making, the study found a negative correlation with turnover intentions. This suggests that employees who are involved in decision making in their banks are less likely to quit their jobs. This finding is consistent with studies by Lambert and Paoline (2008) which found that allowing employees to have input about how their jobs are to be accomplished allows employees to be more effective at their jobs, leading to increased pride and hence greater satisfaction and less intention to turnover.

Procedural justice: On procedural justice, the study found a moderate, significant relationship between procedural justice and intentions to turnover. This suggests that turnover intentions were high among employees who perceived that procedures used by the organizations were unfair. This finding is consistent with studies which have shown that procedurally fair treatment could result in positive organizational outcomes, such as organizational commitment, job satisfaction, low turnover and job performance as employees are more likely to accept the outcomes if the procedures are fair than if they are not (Lambert,2003; Thompson \& Heron,2005; Cropanzano et al.2007).

\section{LIMITATIONS OF THE STUDY}

A few limitations of the study are noted as follows: Firstly, the study was carried out in ten (10) commercial banks in one town in Kenya (Eldoret town). Thus the study findings may be generalised to other banking institutions to a limited extent and to other sectors or industries with caution. Secondly, the study used self-report measures to collect data which are likely to be influenced the participants' perception and emotions at the time of filling the questionnaire. Thirdly, the study was cross-sectional which means that the data was collected at one point in time. This means that the study was unable to capture the long-term effect of HRM practices on turnover intentions. Future studies may carry out a similar study using longitudinal research design. Finally, the bond of secrecy signed by each commercial bank employee not to disclose any information to third parties may have constrained the employees when filling the questionnaires.

\section{CONCLUSIONS AND RECOMMENDATIONS}

The purpose of this study was to establish the effect of demographic characteristics and selected HRM practices on turnover intentions $f$ employees in commercial banks in Eldoret Town, Kenya. The results showed that the mean scores of selected HRM practices differed significantly based on employee demographic characteristics namely; gender, marital status, level of education, age, job tenure and job position. The correlation analysis showed that the selected HRM practices, namely, promotional opportunities, pay practices, participation in decision making and procedural justice had significant negative effect on turnover intentions. This shows that turnover intentions will decline when these practices are 
in line with employees expectations. On the other hand, work/family conflict had significant positive effect on turnover intentions which suggests that employees who are unable to balance their work/family demands were more likely to quit to their jobs due to stress. Finally, the multiple regression analysis has shown that job position, marital status, job tenure, level of education, pay practices and procedural justice had significant effect of turnover intentions.

The findings of this study have important implications for managers of commercial banks. Firstly, the significant effect of the demographic characteristics shows that Bank managers need to recognize the importance of employees because the success of the banks is dependent on committed and productive workforce. This can be achieved through reviewing jobs to ensure that employees perform meaningful and challenging jobs, with skills variety, recognition, provision of competitive pay, training opportunities and adequate promotion opportunities. Secondly, Bank managers need to consider employees perception of human resource practices during formulation and execution of these practices. Well-formulated HR practices, such as pay, promotions and participation in decision making will enhance employees' commitment and thus lower intention to quit. Thirdly, to minimize the negative effect of work/family conflict, banks should create a more supportive work environment with friendly work/family policies that supports employees' family and social life (Lambert, Hogan \& Barton, 2002). Lastly, the present findings have shown that procedural justice has strong effect on turnover intention. Thus, bank managers should ensure fairness in the process of decision making. To achieve this, banks should establish two-way communication so that employees have the opportunity to participate and voice their preferences and opinions during the decision making process (Fatt, Khin \& Heng, 2010).

\section{REFERENCES}

1. Abassi, S. M.\& Hollman, K. W. (2000) Turnover: the real bottom line, Public Personnel Management, 2 (3), pp. 33342

2. Agyeman, C. M. \& Ponniah, V. M. (2014) Employee demographic characteristics and their effects on turnover and retention in MSMEs, International Journal of Recent Advances in Organizational Behaviour and Decision Sciences, 1 (1), pp 12 - 29

3. Allen, N. J. and Meyer, J. P. (1990) The measurement and antecedents of affective, continuance, and normative commitment to the organization. Journal of Occupational Psychology, 63, p. 1-18.

4. Allen, D.G., Shore, L.Y. \& Griffeth, R.W. (2003) The role of perceived organizational support and supportive human resource practices in the turnover process, Journal of Management, 29 (1), 99-118.

5. Altarawmneh, I. \& Al-Kilani, M. H. (2010). Human Resource Management and Turnover Intentions in the Jordanian Hotel Sector. Research and Practice in Human Resource Management, 18(1), 46-59.

6. Batt, R \& Valcour, P. M.(2003) Human resources practices as predictors of work/family outcomes and employee turnover, Industrial Relations: A Journal of Economy and Society, 42 (2), pp. 189-220

7. Bergmann, T.J, Bergmann, M. A and Grahn, J L. (1994) How important are employee benefits to public sector employees. Public Personnel Management, 23, pp 397-406

8. Chiu, Y.L., Chung, R.G., Wu, C.S., \& Ho, C.H. (2009). The effects of job demands, control and social support on hospital clinical nurses' intention to turnover, Applied Nursing Research, 22(4), pp. 258-263.

9. Choong, Y., Keh, C., Tan, Y. \& Tan, C. (2013) Impacts of demographic antecedents toward turnover intention amongst academic staff in Malaysian Private Universities, Australian Journal of Basic and Applied Sciences, 7(6): pp. 46-54

10. Chughtai, A. A. \& Zafar, S. (2006) Antecedents and consequences of organizational commitment among Pakistani University Teachers. Applied H. R. M. Research, 11 (1), p. $39-64$

11. Colquitt, J. A., Conlon, D. E., Wesson, M. J., Porter, C. O. L. H., \& Ng, K. Y. (2001). Justice at the millennium: A metaanalytic review of 25 years of organizational justice research. Journal of Applied Psychology, 86, 425-445

12. Cotton, J.L. and Tuttle, J.F. 1986. Employee turnover: A meta-analysis and review with implications for research. Academy of Management Review, 11(1), pp. 55-70.

13. Cropanzano, R., Bowen, D. E. \& Giiand, S. W. (2007) The management of organisational justice, Academy of Management Perspectives, pp. 34-48

14. Delery, J.E. \& Doty, D. H. (1996) Modes of theorizing in strategic human resource management: Tests of universalistic, contingency, and configurational performance predictions, The Academy of Management Journal, 39 (4), pp. 802-835.

15. Dirks, K. T., \& Ferrin, D. L. (2002). Trust in leadership: Meta-analytic findings and implications for research and practice. Journal of Applied Psychology, 87, 611-628

16. Du Plooy, J. \& Roodt, G. (2013) Biographical and demographical variables as moderators in the prediction of turnover intentions, SA Journal of Industrial Psychology, 39(1)

17. Fatt, C. K., Khin, E. W. S. \& Heng, T. N. (2010) The Impact of Organizational Justice on Employee's Job Satisfaction: The Malaysian Companies Perspectives, American Journal of Economics and Business Administration, 2 (1), pp. 5663 
18. Fuentes, R. C. (2012) The Influence of Demographics, Organizational Commitment and Burnout towards the Turnover Intentions of Teacher, http://www.brokenshire.edu.ph/bcjournal/index.php/sair/article/viewFile/15/pdf 12 (31st October, 2015)

19. Greenberg, J. (1987). Reactions to procedural injustice in payment distributions: Do the means justify the ends? Journal of Applied Psychology, 72, 55-61.

20. Greenhaus, J. H. \& Beutell, N. J. (1985) Sources of conflict between work and family roles, Academy of Management Review, 10 (1), pp. 76 - 88

21. Hai-Yan, K. \& Baum, T. (2006) Skills and work in the hospitality industry sector: The case of hotel front office employees in china, International Journal of Contemporary Hospitality Management, 18(6), pp. 509-518.

22. Iles, P., Mabey, C. \& Robertson, I. (1990) HRM practices and employee commitment: Possibilities, pitfalls and paradoxes. British Journal of Management, 1, pp. 147-157

23. Juhdi, N., Pa'wan, F. \& Hansaram, R. M. K. (2013) HR practices and turnover intention: the mediating roles of organizational commitment and organizational engagement in a selected region in Malaysia, The International Journal of Human Resource Management, 24 (5), pp. 3002-3019

24. Karsh, B., Bookse, B. and Sainfort, F. (2005) Job and organizational determinants of nursing home employee commitment, job satisfaction and intent to turnover. Ergonomics, 48, 1260-1281

25. Kenya Bankers Association (2013) Annual HR Reports of KCB, Equity, National, Barclays and Cooperative Banks

26. Khatri, N., Budhwar, P. \& Chong, T. (2001) Explaining employee turnover in an Asian context, Human Resource Management Journal, 11(1), pp. 54-74.

27. Khilji, S. \& Wang, X. (2007). New evidence in an old debate: Investigating the relationship between HR satisfaction and turnover. International Business Review, 16 (3), pp. 377-395.

28. Kipkebut, D. J. (2013) The Effects of Demographic Characteristics on Organisational Commitment, job Satisfaction and Turnover Intentions: the Case of Employees in Kenyan Universities, Journal of Organization and Human Behaviour $_{2} 2$ (1), pp: $20-33$

29. Komal K. B. \& Samina N. (2011).Determinants of Organizational Commitment in Banking Sector. International Journal of Academic Research, 3 (4), pp. 468-474

30. Lambert, E. G. (2003) Justice in corrections: An exploratory study of the impact of organizational justice on correctional staff. Journal of Criminal Justice, 31, pp. 155-168

31. Lambert, E. \& Hogan, N. (2009) The Importance of Job Satisfaction and Organizational Commitment in Shaping Turnover Intent: A Test of a Causal Model, Criminal Justice Review, 27 (1), pp. 35-52

32. Lambert, E. G., Hogan, N. L., \& Barton, S. M. (2002) The impact of work-family conflict on correctional staff job satisfaction: An exploratory study, American Journal of Criminal Justice, 6(4), pp. 371-387

33. Lambert, E. G., Hogan, N. L., Camp, S. D. \& Ventura, L. A. (2006) The impact of work-family conflict on correctional staff: A preliminary study, Criminology \& Criminal Justice, 6(4), pp. 371-387

34. Lambert, E. G., Hogan, N. L. \& Jiang, S. (2008) Exploring antecedents of five types of organizational commitment among correctional staff: It matters what you measure, Criminal Justice Policy Review, 19 (4), pp. 466-490

35. Lambert, E.G \& Paoline III, N. (2008) The importance of job satisfaction and organizational commitment in shaping turnover intent: A test of a causal model. Criminal Justice Review, 34 (1), pp. 96-118.

36. Mathieu, J. E. \& Zajac, D. M. (1990) A review and meta-analysis of the antecedents, correlates and consequences of organizational commitment. Psychological Bulletin, 108, pp. 171-194

37. McElroy, J. C. (2001) Managing workplace commitment by putting people first. Human Resource Management Review, 11 (3), pp. 327 - 335.

38. Meaghan, S. \& Nick, B. (2002) Voluntary turnover: knowledge management-friend or foe?, Journal of intellectual Capital, 3 (3), pp. 303-322.

39. Meyer, J. P. \& Smith, C. A. (2000) HRM practices and organizational commitment: Test of a mediation model. Canadian Journal of Administrative Sciences, 17(4), pp. 319-31.

40. Michel, Z. Nabeel, N. S. \& ElSharif, A. (2011) The Impact of Human Resource Management Practices on Organizational Commitment in the Banking Sector in Kuwait. International journal of Business and Management, 6 (6)

41. Miller, J.G. \& Wheeler, K. G. (1992) Unraveling the mysteries of gender differences in intentions to leave the organization, Journal of Organizational Behavior, 13, pp. 465-478.

42. Mudor, H. \& Tooksoon, P. (2011) Conceptual framework on the relationship between human resource management practices, job satisfaction, and turnover, Journal of Economics and Behavioral Studies, 2 (2), pp.41-49 
43. Ng, T. W. H., \& Sorensen, K. L. (2008) Toward a Further Understanding of the Relationships between Perceptions of Support and Work Attitudes - A Meta-Analysis, Group and Organization Management, 33 (3), pp. 243-268

44. Ngigi, E. W. \& Kipkebut, D. J. (2014) Effect of employee demographic characteristics and job characteristics on job satisfaction among employees in the banking industry: A case of commercial banks in Nakuru Town, Kenya, International Journal of Management \& Information Technology, 9 (3) pp. 1698-1711

45. Nivethitha, S., Dyaram, L. \& Kamalanabhan T.J. (2014) Relationship between Human Resource Practices and Employee Turnover Intention in Hospitality Industry, Global Journal of Management and Business Research Administration and Management, 14 (1), pp. 34-42

46. Ovadje, F. (2009) Exploring Turnover among Middle Managers in a non-Western Context, International Journal of Business Research, 10 (2), pp. 64-80

47. Poon, J. M. L. (2012) Distributive Justice, Procedural Justice, Affective Commitment, and Turnover Intention: A Mediation-Moderation Framework, Journal of Applied Social Psychology, 42 (6), pp. 1505-1532

48. Quarles, R. (1994) An examination of promotion opportunities and evaluation criteria as mechanisms for affecting internal auditor, Journal of Managerial Issues, 6 (2), pp. 176-194.

49. Thompson, M. \& Heron, P. (2006) Relational quality and innovative performance in R \& D based Science and Technology firms, HRM Journal, 16 (1), pp. 28-47

50. Wasti, S. A. (2003) The influence of cultural values on antecedents of organizational commitment: an individual-level analysis. Applied Psychology: An International Review, 52 (4), pp. 533-554

51. Whitener, E. M. (2001) Do "high commitment" human resource practices affect employee commitment? A cross-level analysis using hierarchical linear modeling, Journal of Management, 27 (5), pp. 515 - 535

52. Wright, S. C., Aron, A., McLaughlin-Volpe, T. \& Ropp, S. A. (1997) The extended contact effect: Knowledge of crossgroup friendship and prejudice, Journal of Personality and Social Psychology, 73, pp. 73 - 90

53. Yousef, D.A. (2002) Job Satisfaction as a Mediator of the Relationship between Role Stressors and Organizational Commitment. A Study from an Arabic Perspective, Journal of Managerial Psychology 17(4), pp. 250-66. 